\title{
Iranian and Non-Iranian Social Networks' Structures; A Comparative Study
}

\author{
Seyed Reza Naghibulsadat, Allameh Tabatabai University, Iran \\ Fatemeh Qasabi, AllamehTabatabaee University, Iran \\ Parisa Farhadi, AllamehTabatabaee University, Iran
}

\begin{abstract}
This research attempts to present a picture of the structure and design of virtual social networking sites such as Facenama, Cloob, Facebook, and Google+. The aim of this research is to study what are the differences between Iranian and non-Iranian social networks structures mainly used by Iranian users. Content analysis method has been used in the present research. Elements such as real images, personal photos, high attractiveness, image plus text, warm and cool colors, lots of comments (more than ten comments), and minimal use of symbolic signs have been used more than other types. Moreover, it was identified that there is no significant difference between the type of selected structures by users in Iranian and non-Iranian social network websites. The results of the research could be use to reach a pattern of use of these websites for creating and developing personal social networking.
\end{abstract}

Keywords: Social Networks; Structures; Iranian 


\section{Introduction}

Social networking websites nowadays have become a global phenomenon and have created the virtual community with hundreds of millions of users and the number of users is increasing every day. This cyberspace provides the possibility of establishing friendly environment and interactions. Individuals select their favorite website themselves and become a member of it. These networks have been widely accepted by the users due to their diversity and variety of contents. Cyberspaces are interlocking like the wrap of spider and have made a complex structure. This virtual space has attracted many users towards itself due to its being attractive and available. The main question raised in this research is: what are the differences in the structure and design of Iranian and non-Iranian social networking sites? The space created by social networking sites has made people interact each other more and more. The space which is provided for the users by the social networking sites provides an opportunity for the users to display their profiles based on their beliefs, interests, and ideas in a structure with special form and the contents which cover their interests.

\section{Theoretical Framework}

Socialnetworking sites areclassified as a subsetofsocial media. Social media are general concepts which have emerged within the new technologies such as internet, cell phone, social networks, etc.Social networking sites have been established based on the interests of individuals and groups and have been created by a kind of public participation. In social networking sites it is possible to develop direct communication and interaction. It is possible to transfer information through email but not concurrently. Such concurrency is observed in social networking sites and these networks are able toexchange information among various individuals. Ziaeihas defined some social networking features as: "sharing, mobilization, organizing, making friendship and trust, creating chains of audience, citation and generalization, multimedia, brutal review, following and being followed, prestige, open publishing, universality, entertainment, democratic structure, social capital power, social mobility, innovation, and creativity." (ZiaeiParvar, 2009). Wellman says, "A social network is a set of relevant social groups that are connected to each other through one or several relations. Such units are most often individuals or organizations. In fact, each unit that can be connected to the other units might be studied as the groups (Rajabi, 2009). 
Virtual social networks are a part of social media. In fact, they are weblogs from Web 2 Generation with the following features:

A. They only play the role of a facilitator to convey information and the key role of user in creating the content is preserved. Therefore, the information available in this space is real and can be investigated and the result can be generalized.

B. They are democratized. That is, individuals can create and follow their favorite groups and interests in this space regardless of their economic, social, religious, and educational status.

C. They are distinguished. The content producer in this space is also a part of it.The smallest and the least important comments are seen or heard in this space, and could be effective while on the outside of the virtual networks they might be lost or not be counted for in complexities of today's routine.

D. Convergence has occurred on different types of media. In this space individuals express and share their ideas and feelings with an evolved package of modern communicative technologies.

E. The content producer and consumer are the same. Therefore, this space does not merely useby a particular group. It permits everyone to emerge and manifest. Moreover, the presence of different people provides a more generalized context (MousaviNasab, 2011, 57).

People often access information, resources, and opportunities through their own personal relationships. These relationships form the social network of individuals that in turn creates the social system. Social scientists have used the concept of social network to refer to the complex system of the relationships between people in the social system (Soltanifar, 2007).

Social networking websites have become popular for different reasons and have encouraged the users to participate in them. The two most important reasons are: First, networking factor itself: the ability to form different networks with individuals who have common location, political views, ideas, and diversions. Secondreason is the fact that users want to make their own content without the need to take responsibility for the establishment and administration of the website. The users' generated content has enabled millions of people to express their opinions, ideologies, and feelings and get aware of the ideas and opinions of other people. The users of social 
networking websites are now able to do exactly what they want to and to choose any kind of social relation they like (Rajabi, 2009).

Wellman (1988) has stated that the rules and patterns of interaction create the structure. He believes that social networks can be used effectively to extract pattern from them. He suggests some defaults in social network theory:

1. The society moves from the hierarchical structure towards the network and multi-group structure.

2. Social capital (Bourdieu,1984) is hidden in social networks.

3. Comprehending the patterns is important in making analytical methods and recognizing the network.

4. Structured relations help to explain macro social systems.

5. Social structures can affect interpersonal relationships.

6. The world is composed of networks not groups (Babaei, 2011).

In 2009, Steve Jones and Sarah Millermaierpublished a research entitled " Whose space is MySpace? A content analysis of MySpace profiles " in the Journal of Computer-Mediated Communication. In this study, they identified the type of personal information that users shared in their profiles. The researchers used content analysis method in conducting the research in order to find the personal characteristics of the users and the type of shared content in users' profiles.The results showed that such virtual social networks are used for creating and developing individual identity and establishing online relationships. The findings also revealed a high level of the privacy control by the users. The results indicated that MySpace virtual network is used not only as a communication tool but also for self-disclosure and the construction of identity.

Noel and Chamberlain in 2011 published an article entitled "A picture is worth a thousand words: A content analysis of Facebook profile photographs" in the Journal of Computer in Human Behavior. The research examined identity construction and the role of gender in the use of virtual social networks and compared the photos in the profiles of male and female users of 
Facebook. The number of uploaded photos on the page and the content of photos have been analyzed, and the researchers have found that the number of uploaded photo differ significantly by gender. The participants in the research were male and female student aged 18-23. The content and amount of Facebook profile photographs also did not significantly vary by gender.

\section{Objectives and Questions}

The main objective of this research is to identify the structure and design of Iranian and nonIranian social networks in order to somewhat compare the structure of Iranian and foreign social networks and to determine their structural similarities and differences. The results of the research could be use to reach a pattern of use of these websites for creating and developing personal social networking. The main question of the research is: What are the differences between the structure and design of Iranian and non-Iranian social networks?

To answer the question variables such as the kind of uploaded photos, profile picture, design template attractiveness, colors, number of comments, number of visitors, type of the shared content in social networks are analyzed and compared in Iranian and non-Iranian social networks.

\section{Research Method}

In this research, content analysis method is used. The analysis unit is profile page. The research population is made up of two Iranian (Facenama and Cloob), and two foreign social networking websites (Facebook and Google+). The sample size has been estimated according to Cochran's sample size formula. 384 pages of these four networks have been investigated.

The samples for the research were selected by simple random samplingamong four websites. The collected data were analyzed by SPSS software. 


\section{Research Findings \& Data Analysis}

Table 1. Type of profile picture in Iranian and Non-Iranian Social Networks

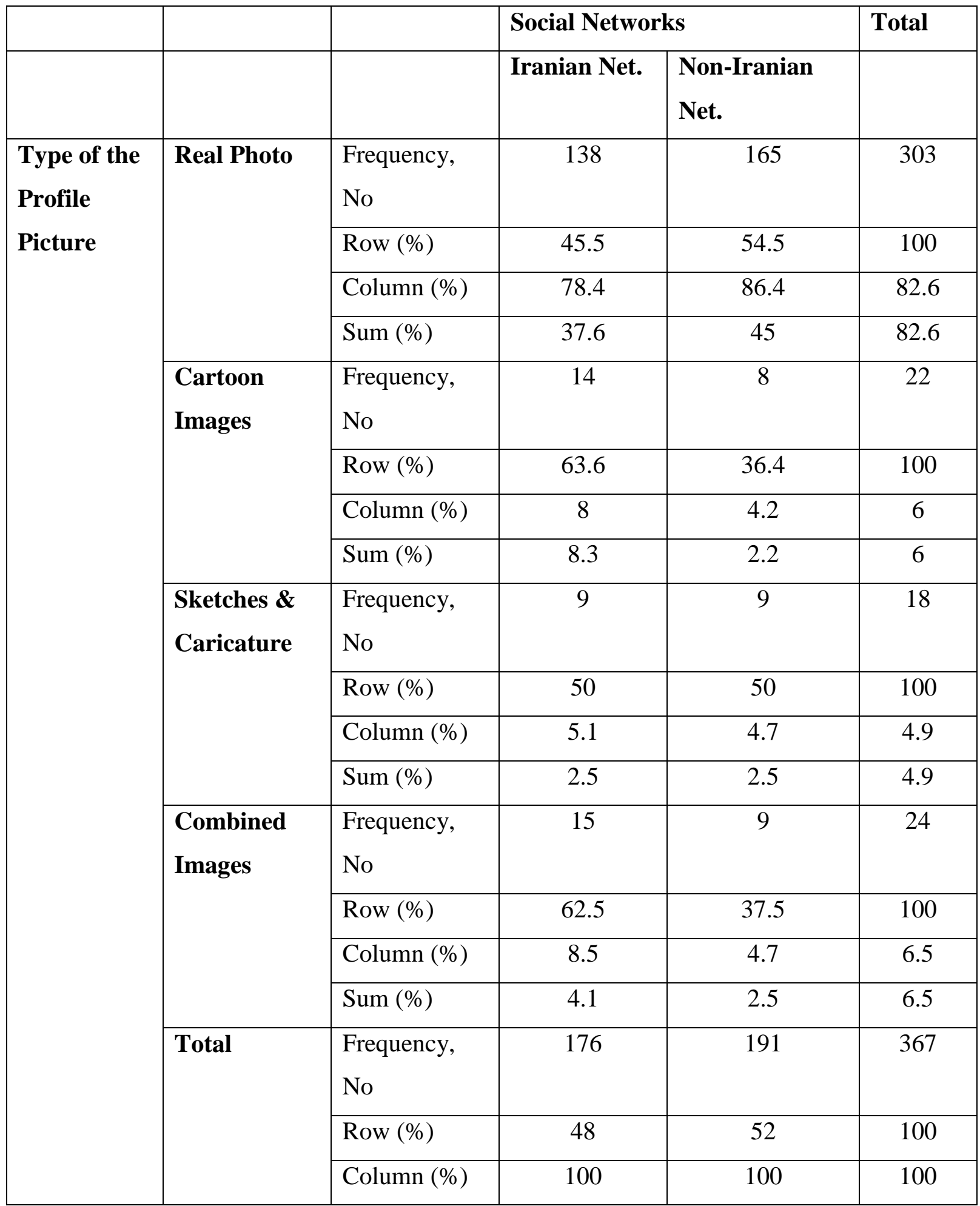




\begin{tabular}{|l|l|l|l|l|l|}
\hline & & Sum (\%) & 48 & 52 & 100 \\
\hline
\end{tabular}

$X^{2}: 4.937$ df: 3 Sig.: 0.176

Table (1) shows that in both Iranian and foreign social networking websites real photos had the highest rate of types of profile pictures and caricature had the lowest rate among other types.

Table 2. Type of the Real photos (used for the profile picture) in Iranian and non-Iranian Social networks

\begin{tabular}{|c|c|c|c|c|c|}
\hline & & & \multicolumn{2}{|c|}{ Social Networks } & \multirow[t]{2}{*}{ Total } \\
\hline & & & $\begin{array}{c}\text { Iranian } \\
\text { Net. }\end{array}$ & $\begin{array}{c}\text { Non-Iranian } \\
\text { Net. }\end{array}$ & \\
\hline \multirow{16}{*}{$\begin{array}{c}\text { Type of } \\
\text { the Real } \\
\text { Photo }\end{array}$} & \multirow[t]{4}{*}{$\begin{array}{l}\text { Nature } \\
\text { View }\end{array}$} & $\begin{array}{l}\text { Frequency, } \\
\text { No }\end{array}$ & 15 & 4 & 19 \\
\hline & & Row (\%) & 78.9 & 21.1 & 100 \\
\hline & & Column (\%) & 10.5 & 2.4 & 6.2 \\
\hline & & Sum (\%) & 4.9 & 1.3 & 6.2 \\
\hline & \multirow[t]{4}{*}{ Friends } & $\begin{array}{l}\text { Frequency, } \\
\text { No }\end{array}$ & 16 & 2 & 18 \\
\hline & & Row (\%) & 88.9 & 11.1 & 100 \\
\hline & & Column (\%) & 11.2 & 2.1 & 5.9 \\
\hline & & Sum (\%) & 5.2 & 0.7 & 5.9 \\
\hline & \multirow[t]{4}{*}{ Familly } & $\begin{array}{l}\text { Frequency, } \\
\text { No }\end{array}$ & 18 & 7 & 25 \\
\hline & & Row (\%) & 72 & 28 & 100 \\
\hline & & Column (\%) & 12.6 & 4.3 & 8.1 \\
\hline & & Sum (\%) & 5.9 & 2.3 & 8.1 \\
\hline & \multirow[t]{4}{*}{ Personal } & $\begin{array}{l}\text { Frequency, } \\
\text { No }\end{array}$ & 78 & 140 & 218 \\
\hline & & Row (\%) & 35.8 & 64.2 & 100 \\
\hline & & Column (\%) & 54.5 & 85.4 & 71 \\
\hline & & Sum (\%) & 25.4 & 45.6 & 71 \\
\hline
\end{tabular}




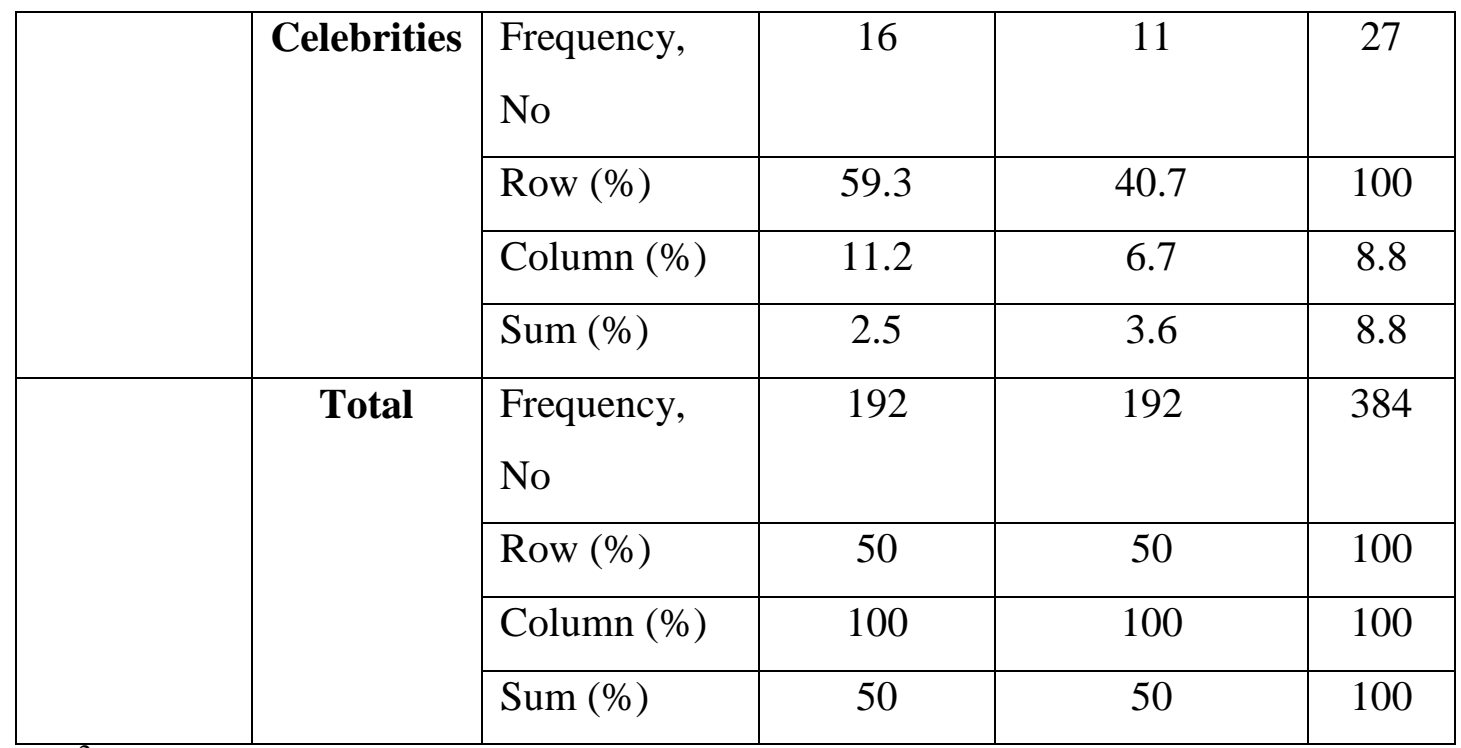

$X^{2}: 39.404 \quad$ df: $4 \quad$ Sig.: 0.000

Table (2) shows the highest rate of real photos belonged to personal photos and the lowest rate belonged to the photos of friends in both Iranian and non-Iranian social networks.

Table 3.Shared content format in Iranian and non-iranian Social Networks

\begin{tabular}{|c|c|c|c|c|c|}
\hline & & & \multicolumn{2}{|c|}{ Social Networks } & \multirow[t]{2}{*}{ Total } \\
\hline & & & Iranian Net. & $\begin{array}{l}\text { Non-Iranian } \\
\text { Net. }\end{array}$ & \\
\hline \multirow{9}{*}{$\begin{array}{l}\text { Format of } \\
\text { the } \\
\text { content }\end{array}$} & \multirow[t]{4}{*}{ Text } & $\begin{array}{l}\text { Frequency, } \\
\text { No }\end{array}$ & 83 & 5 & 88 \\
\hline & & Row (\%) & 94.3 & 5.7 & 100 \\
\hline & & Column (\%) & 43.2 & 2.6 & 32.9 \\
\hline & & Sum (\%) & 21.6 & 1.3 & 22.9 \\
\hline & \multirow[t]{4}{*}{ Text+Picture } & $\begin{array}{l}\text { Frequency, } \\
\text { No }\end{array}$ & 102 & 104 & 206 \\
\hline & & Row (\%) & 49.5 & 50.5 & 100 \\
\hline & & Column (\%) & 53.1 & 54.2 & 53.6 \\
\hline & & Sum (\%) & 26.6 & 27.1 & 53.6 \\
\hline & Text + & Frequency, & 1 & 8 & 9 \\
\hline
\end{tabular}




\begin{tabular}{|c|c|c|c|c|}
\hline \multirow[t]{4}{*}{ audio } & No & & & \\
\hline & Row $(\%)$ & 11.1 & 88.9 & 100 \\
\hline & Column (\%) & 0.5 & 4.2 & 2.3 \\
\hline & Sum (\%) & 0.3 & 2.1 & 2.3 \\
\hline \multirow[t]{4}{*}{$\begin{array}{l}\text { Multi } \\
\text { Media }\end{array}$} & $\begin{array}{l}\text { Frequency, } \\
\text { No }\end{array}$ & 6 & 75 & 81 \\
\hline & Row (\%) & 7.4 & 92.6 & 100 \\
\hline & Column (\%) & 3.1 & 39.1 & 21.1 \\
\hline & Sum $(\%)$ & 1.6 & 19.5 & 21.1 \\
\hline \multirow[t]{4}{*}{\begin{tabular}{|l|} 
Total \\
\end{tabular}} & $\begin{array}{l}\text { Frequency, } \\
\text { No }\end{array}$ & 192 & 192 & 384 \\
\hline & Row (\%) & 50 & 50 & 100 \\
\hline & Column (\%) & 100 & 100 & 100 \\
\hline & Sum $(\%)$ & 50 & 50 & 100 \\
\hline
\end{tabular}

$X^{2}: 1.334$ df: $3 \quad$ Sig.: 0.000

Table (3) indicates that the highest rate of shared content format for both Iranian and foreign social networks was the format of (text + image) and the lowest rate of content production format for both Iranian and non-Iranian social networks was the format of (text + audio) which the lowest rate among all was related to Iranian social networks.

Table 4.Colors in Iranian and non-iranian Social Networks

\begin{tabular}{|c|c|l|c|c|c|}
\hline & & & \multicolumn{2}{|c|}{ Social Networks } & Total \\
\hline \multirow{3}{*}{ Colors } & \multirow{3}{*}{$\begin{array}{c}\text { Warm } \\
\text { Colors }\end{array}$} & $\begin{array}{c}\text { Iranian } \\
\text { Net. }\end{array}$ & $\begin{array}{c}\text { Non-Iranian } \\
\text { Net. }\end{array}$ & \\
\cline { 3 - 6 } & No & 35 & 37 & 72 \\
\cline { 3 - 6 } & Row (\%) & 48.6 & 51.4 & 100 \\
\cline { 3 - 6 } & & Column (\%) & 18.2 & 19.3 & 18.8 \\
\cline { 3 - 6 } & Sum (\%) & 9.1 & 9.6 & 18.8 \\
\hline
\end{tabular}




\begin{tabular}{|c|c|c|c|c|}
\hline \multirow[t]{4}{*}{$\begin{array}{l}\text { Cold } \\
\text { Colors }\end{array}$} & $\begin{array}{l}\text { Frequency, } \\
\text { No }\end{array}$ & 37 & 8 & 45 \\
\hline & Row (\%) & 82.2 & 17.8 & 100 \\
\hline & Column (\%) & 19.3 & 4.2 & 11.7 \\
\hline & Sum (\%) & 9.6 & 2.1 & 11.7 \\
\hline \multirow{4}{*}{$\begin{array}{c}\text { Warm \& } \\
\text { Cold } \\
\text { Colors }\end{array}$} & $\begin{array}{l}\text { Frequency, } \\
\text { No }\end{array}$ & 87 & 125 & 212 \\
\hline & Row (\%) & 41 & 59 & 100 \\
\hline & Column (\%) & 45.3 & 65.1 & 55.2 \\
\hline & Sum $(\%)$ & 22.7 & 32.6 & 55.2 \\
\hline \multirow[t]{4}{*}{$\begin{array}{c}\text { Black \& } \\
\text { Wight }\end{array}$} & $\begin{array}{l}\text { Frequency, } \\
\text { No }\end{array}$ & 33 & 22 & 55 \\
\hline & Row (\%) & 60 & 40 & 100 \\
\hline & Column (\%) & 17.2 & 11.5 & 14.3 \\
\hline & Sum (\%) & 8.6 & 5.7 & 14.3 \\
\hline \multirow[t]{4}{*}{ Total } & $\begin{array}{l}\text { Frequency, } \\
\text { No }\end{array}$ & 192 & 192 & 384 \\
\hline & Row (\%) & 50 & 50 & 100 \\
\hline & Column (\%) & 100 & 100 & 100 \\
\hline & Sum $(\%)$ & 50 & 50 & 100 \\
\hline
\end{tabular}

$X^{2}: 27.756$ df: 3 Sig.: 0.000

Table (4) shows that the highest ratio of color in both Iranian and non-Iranian social networks belonged to warm and cool colors and the highest rate of application of those colors belonged to non-Iranian social networks. The lowest ratio of color for both Iranian and non-Iranian social networks belonged to cool colors and the lowest rate of application of cool colors belonged to non-Iranian social networks. 
Table 5.Number of comments by users in Iranian and non-iranian networks (The maximum number of comments in a profile page has been counted )

\begin{tabular}{|c|c|c|c|c|c|}
\hline & & & \multicolumn{2}{|c|}{ Social Networks } & \multirow[t]{2}{*}{ Total } \\
\hline & & & $\begin{array}{c}\text { Iranian } \\
\text { Net. }\end{array}$ & $\begin{array}{c}\text { Non-Iranian } \\
\text { Net. }\end{array}$ & \\
\hline \multirow[t]{20}{*}{$\begin{array}{l}\text { Number of } \\
\text { Comments }\end{array}$} & \multirow[t]{4}{*}{$\begin{array}{c}\text { No } \\
\text { Comment }\end{array}$} & $\begin{array}{l}\text { Frequency, } \\
\text { No }\end{array}$ & 27 & 11 & 38 \\
\hline & & Row (\%) & 71.1 & 28.9 & 100 \\
\hline & & Column (\%) & 14.1 & 5.7 & 9.9 \\
\hline & & $\operatorname{Sum}(\%)$ & 7 & 2.9 & 9.9 \\
\hline & \multirow[t]{4}{*}{$\begin{array}{l}\text { Btwn 1-5 } \\
\text { Comment }\end{array}$} & $\begin{array}{l}\text { Frequency, } \\
\text { No }\end{array}$ & 68 & 36 & 104 \\
\hline & & Row (\%) & 65.4 & 34.6 & 100 \\
\hline & & Column (\%) & 35.4 & 18.8 & 27.1 \\
\hline & & $\operatorname{Sum}(\%)$ & 17.7 & 9.4 & 27.1 \\
\hline & \multirow{4}{*}{$\begin{array}{c}\text { Btwn 6- } \\
10 \\
\text { Comment } \\
\text { s }\end{array}$} & $\begin{array}{l}\text { Frequency, } \\
\text { No }\end{array}$ & 53 & 55 & 108 \\
\hline & & Row (\%) & 49.1 & 50.9 & 100 \\
\hline & & Column (\%) & 27.6 & 28.6 & 28.1 \\
\hline & & $\operatorname{Sum}(\%)$ & 13.8 & 14.3 & 28.1 \\
\hline & \multirow{4}{*}{$\begin{array}{c}\text { More } \\
\text { than } 10 \\
\text { Coments }\end{array}$} & $\begin{array}{l}\text { Frequency, } \\
\text { No }\end{array}$ & 44 & 90 & 134 \\
\hline & & Row (\%) & 32.8 & 67.2 & 100 \\
\hline & & Column (\%) & 22.9 & 46.9 & 34.9 \\
\hline & & $\operatorname{Sum}(\%)$ & 11.5 & 23.4 & 34.9 \\
\hline & \multirow[t]{4}{*}{ Total } & $\begin{array}{l}\text { Frequency, } \\
\text { No }\end{array}$ & 192 & 192 & 384 \\
\hline & & Row (\%) & 50 & 50 & 100 \\
\hline & & Column (\%) & 100 & 100 & 100 \\
\hline & & $\operatorname{Sum}(\%)$ & 50 & 50 & 100 \\
\hline
\end{tabular}




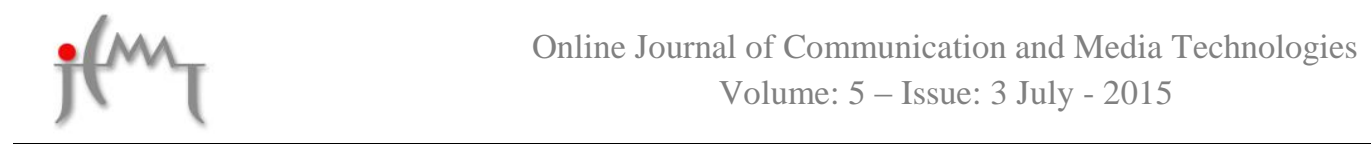

$$
X^{2}: 32.411 \quad \text { df: } 3 \quad \text { Sig.: } 0.000
$$

Table (5) shows that the maximum ratio of number of the comments in both Iranian and nonIranian social networks was more than 10 comments and the highest number of comments belonged to foreign social networks. The minimum ratio of comments in Iranian and non-Iranian social networks was zero which belonged to non-Iranian social networks.

\section{Discussion}

The images used in Iranian and non-Iranian social networking profiles in terms of the rate of application are real photos, cartoons, caricature, andcombined photos (respectively). The highest rate of real photo belongs to personal photos used in non-Iranian social networks which indicate that Iranian users in non-Iranian social networks prefer to display their own photos more than others' photos.

The results of the research show that the majority of users use designing format for their personal page and try to choose formats which are more attractive. Most users use the format which is offered by the network itself for designing their own page and fewer users use new formats themselves. In non-Iranian social networks also the format of network is often used.

The contents' form in profile pages is mainly as (text + picture). Most users use contents which are easily accessible and do not need much time to upload. One of the things which are always used for justification and more attractiveness is the application of colors. Colors reflect the individual's personality on one hand, and attract the users more, on the other hand. In Iranian and non-Iranian social networks warm, cool, warm and cool, black and white colors have been used. The highest ratio of colors belongs to the use of both warm and cool colors (together) which is seen in non-Iranian social networks. It should be noted that some attractions are used to make colors more attractive and in this researchit has been seen that emotional attractions were mainly used. One of the social networking features provided for the users is putting comments about the contents. In this research the volume of comments was relatively high and there were more than 10 comments on each point. 
It seems that the space which is provided for the users by social networks is an open and free space. This space is displayed in the symbolic signs which somewhat refer to the group or organization that an individual belongs to. According to the results most users have not used symbolic signs. In other words, they didn't belong to a special group or organization and fewer users have used such signs in their profiles. As mentioned earlier and according to the theory of networking society and network theory, structure in social networks is an important feature. This feature refers to what is noticed by the user at the first glance which is seen in photos, formats, colors, content production form, and comments. Social networking structures are different from each other, but they all provide a series of facilities for their users, so that the users can display according to their own interests. In general, structure is the framework of a network and each user can make it more attractive and attract more users to his/her own profile. Users in Iranian social networks have somewhat observed Iranian culture in their structure and design and have tried to use structures that match local and national culture. Moreover, the users in non-Iranian social networks have been relatively more active than the users in Iranian social networks and have tried to make the structure and design of their profiles more attractive.

This broad, yet deep study also shows that Iranians, particularly young ones $(67.2 \%$ of the profile pages belonged to under 30 years olds), have an interestingly similar behavior in both domestic and western based virtual spaces. This valuable fact shows that modern information technology has deterritorized modern nation-state borders in the era of Globalization. To put it more plainly, modern virtual spaces are the most significant manifestations of globalization forces, bypassing state surveillance. In fact, challenging dominant codes is at the center of virtual spaces.

These virtual spaces imply a network of affiliations in a society of a pariah state. Such socially submerged networks form the foundation of the collective identity, in the sense that they make identification and recognition possible, as well as calculation and prediction ofthe effects of actions (Reisinezhad, 2014). From this perspective, Iranian virtual spaces serve as "articulating spaces" that homogenizes and integrates dominant global culture in marginal realms, here the 
Iranian society. In other words, these networks, structuring relations, are not only confined to more palpable realms, but also include the intersection of the practice of everyday life, collective action, and politics(Reisinezhad, 2014).They are embedded in quotidian relationships and thus more impervious to state control(Scott 1990, Zuo 1995, Zhao 1998, Loveman 1998).It islife within groups that transforms the culture of the young.In short, informal networks construct "free spaces" in which ordinary people build and expand theirmutual ties .

The integration of domestic virtual spaces in Iran and their similarity with famous virtual spaces stressesthe significance of informal aspect of social networks and their effectiveness, particularly in less open polities where visibility is dangerous and in high-risk milieu where the informal social ties provide bonds of trust and solidarity beyond the regimesurveillance (Reisinezhad, 2014).Tightly knit networks nurture collective identities and solidarity; provide informal organization and contacts, and supply information otherwise unavailable to individuals (Pfaff, 1996).

For future studies the cultural role of these networks should be underscored. Social networks are spaces for themeaning production. The ultimate outcome of such acovertly cultural process is the quotidian production of alternative meaning which nourishes the Iranian young. 


\section{References}

Babaei M. Cyber space and the discourse patterns. Doctoral thesis dissertation. Tehran. AllamehTabatabaee University. 2011

Bourdieu P. Distinction: A social critique of the Judgment of Taste. Routledge publications. 1984

Jones S, Millermaier S, Goya-Martinez M, Schuler J. Whose space is MySpace? A content analysis of MySpace profiles. J Computer-Mediated communication. 13(9): 2008

Loveman M. High-risk collective action: Defending human rights in Chile, Uraguay, and Argentina. AJS. 1998: 104(2); 477-52

Mousavinasab L. How social networking effects people's social capital (master dissertation). Tehran. AllamehTabatabaee University. 2011

Noelle J. HUM \& E. Chamberlin, Perrin. "A picture is worth a thousand words: A content analysis of Facebook profile photographs", Computers in Human Behavior. 27,5:182833. 2011

Pfaff S, "Collective Identity and Informal Groups in Revolutionary Mobilization: East Germany in 1989". Social Forces: 75 (September); 91-118.

Rajabi Z. Reconstruction of users political inclinations in virtual social networks. Master dissertation. Tehran. AllamehTabatabaee University. 2010

Reisinezhad A. "The Iranian Green Movement: Fragmented Collective Action and Fragile Collective Identity”. Iranian Studies (published in March, 2014) (http://www.tandfonline.com/doi/abs/10.1080/00210862.2013.859885?journalCode=cist2 0\#.UxTmMfldVIV)

Scott JC. Domination and the Arts of Resistance: The hidden transcript of subordinate Groups. Yale University Press. 1990.

Soltanifar M. Social networks, opportunities and challenges. Center of Strategic Researches. 2007

ZiaeiParvar H. Characteristics of Virtual Social Networks. Center of Strategic Researches. 2009

Zhao, Dingxin. Ecologies of Social Movements: Student Mobilization during 1989 ProDemocracy Movement in Beijing. American J Sociology. 1998: 103(6); 1493-1529. 
Zuo J, Benford RD. Mobilization Processes and the 1989 Chinese Democracy Movement. The Sociological Quarterly. 1995: 36(1); 131-56

www. cloob. com.

www. facebook. com.

www. facenama. com.

www. plus. google. com 